\title{
金昆羅大芝居の研究 $(1)$
}

成立の背景と建設

正会員佐 藤 孝 義*

前 書

此の研究は 昭和 43 年 3 月, 日本大学芸術学部演劇学 科と同生産工学部建築工学科佐藤研究室とが現地で合同 調查を行った事から始った。筆者は劇場の実測調査を担 当したが，建築計画の立場から劇場の空間的スケールに 興味を持ら研究を進め,すでにその概略を日本建築学会 大会学術講演会等に報告した(注 1 )。

本稿は琴平町の直営で 復元の為, 炤和 48 年から始め られた解体修理の過程で得られた新しい資料等も加え， 新たに稿を起したものである。

本稿は本劇場が金毘羅宮の門前町に存在する意味とそ の背景について考察し，定小屋として建設された経過と 年代考証を扱った。

古典の様式に基づいた歌舞伎の演出と演技は，現在可 成り保存され上演されているが，昔どの様な空間の内で
演技がなされていたかは今は史料の上でしか窥う事が出 来ない。本劇場が創建時の様式に復元出来れば，役者の 振りの大きさや, 衣裳の柄の識別, 台詞や演奏の音の問 題等, 劇場空間が躣し出寸効果を確認する事が可能であ る。此の事が劇場史にとっても演劇史にとっても意義深 いものであると考える。

金毘羅大芝居の劇場は，琴平町によって 昭和 51 年 4 月，香川県，文化庁等の協力を得て，発祥の地である金 山寺の敷地を離れ，象頭山山内の新しい敷地に於て復元 された。

\section{1. 金昆羅大芝居成立の背景}

1）門前町と市立

江戸中期頃からの民酓の神仏信仰の高まりと，宮中か ら栜願所と 日本一社の綸旨を受ける(注 2) 等の権威の裏 付けにより，金毘羅参詣は次第に増加し，伊勢神宮，善

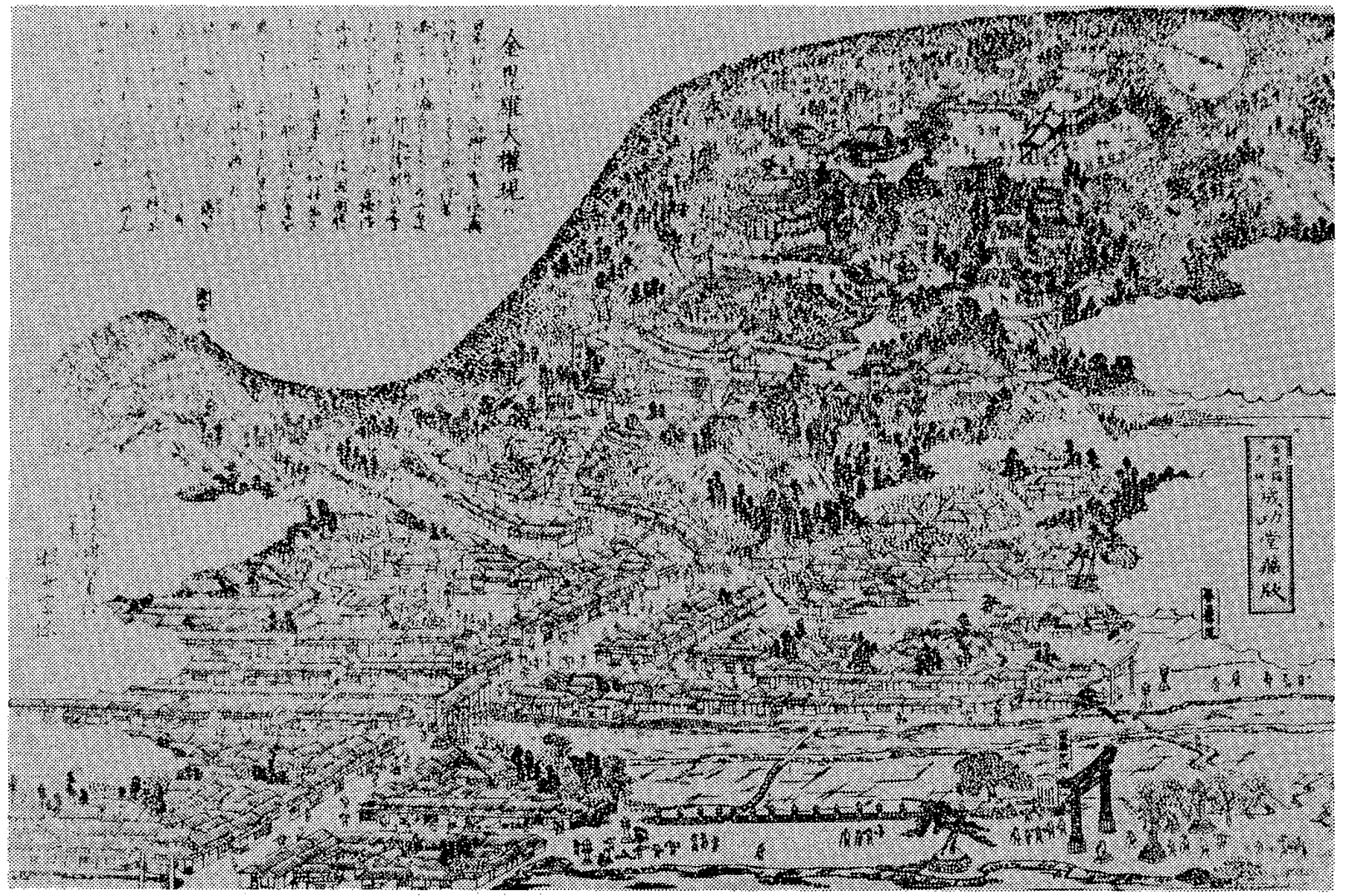

図-1 成功堂蔵版 金毘羅絵図

* 日本大学教授

（昭和 51 年 7 月 2 日本稿受理・討論期限昭和 52 年 10 月末日） 
金毘羅山内人口調

\begin{tabular}{|c|c|c|c|c|c|c|c|}
\hline 年 代 & 総人口 & $\begin{array}{l}\text { 金光院 } \\
\text { 係者 }\end{array}$ & 百 姓 & 町 人 & その他 & 家 数 & 出典史 料 \\
\hline $\begin{array}{c}\text { 亭保 } 6 \text { 年 } 7 \text { 月 } \\
(1721)\end{array}$ & $\begin{array}{rr}2465 \\
\text { 男 } & 1319 \\
\text { 女 } & 1146 \\
\end{array}$ & $\begin{array}{c}375 \\
\text { 男 } 195 \\
\text { 女 } 180 \\
\end{array}$ & $\begin{array}{cc} & 145 \\
\text { 男 } & 88 \\
\text { 女 } & 57\end{array}$ & \begin{tabular}{cr}
\multicolumn{2}{c}{1910} \\
男 & 1003 \\
女 & 907
\end{tabular} & 35 & & $\begin{array}{l}\text { 金䍡羅社領人数書上帳 } \\
\text { 金刀比羅宦社務所所蔵 }\end{array}$ \\
\hline $\begin{array}{c}\text { 宝笶11年 } 5 \text { 月 } \\
\text { (1761) }\end{array}$ & 2000 & & & & & $\begin{array}{l}350 \text { 軒 } \\
\text { 琶 } 780 \\
\end{array}$ & $\begin{array}{l}\text { 巡見史料 } \\
\text { 金刀比羅宮社務所所蔵 }\end{array}$ \\
\hline $\begin{array}{c}\text { 寛政元年 } 4 \text { 月 } \\
(1789)\end{array}$ & $\begin{array}{rr} & 1959 \\
\text { 男 } & 1129 \\
\text { 女 } & 830\end{array}$ & & & & & & $\begin{array}{l}\text { 巡見史料 } \\
\text { 金刀比羅宮社務㫹所藏 }\end{array}$ \\
\hline $\begin{array}{c}\text { 天 保 } 11 \text { 年 } \\
(1840)\end{array}$ & $\begin{array}{rr} & 2781 \\
\text { 男 } & 1476 \\
\text { 女 } & 1350 \\
\end{array}$ & $\begin{array}{r}786 \\
\text { 男 } 408 \\
\text { 女 } 378 \\
\end{array}$ & $\begin{array}{r}317 \\
\text { 男 } 175 \\
\text { 女 } 142 \\
\end{array}$ & \begin{tabular}{cr|} 
& 1654 \\
男 & 893 \\
女 & 761 \\
\end{tabular} & 24 & & $\begin{array}{l}\text { 金毘羅社領人数分党 } \\
\text { 金刀比羅宮社務所所蔵 }\end{array}$ \\
\hline $\begin{array}{c}\text { 慶応 } 4 \text { 年 } 2 \text { 月 } \\
\quad(1868)\end{array}$ & 3442 & 703 & 334 & 2372 & 33 & 928 軒 & $\begin{array}{l}\text { 社預分戸口人員 } \\
\text { 金刀比羅宮社務所所蔵 }\end{array}$ \\
\hline
\end{tabular}

の経路として闍前町に集っていた。金 毘羅の門前町は此等の街道の集約した 場所に形造られて行った。

10 月と 6 月の 金昆羅の会式は,「古 老伝旧記」(注6)によれば，文永 7 年 (1270) と観㦄 3 年 (1352) の間頃加ら は確実にあったさ考えられる。10月 の会式では大祭と市立が行われ，6月 は観音大市と呼ばれた。3 月市は稍新 しく，新市と呼ばれ 正保 2 年 (1645) と寬文 6 年 (1666)の閒に始り，花立 市(注7)と呼ばれた。

享保 2 年 (1717) 以前 と考えられる 「金毘羅祭礼図屏風」(注 8 , 図2)には，金毘羅参詣の旅人 や繁栄して居る街並の様子，風俗が描写されて居る。特 に能舞台掛りの掛小屋, 操り人形の掛った小屋等が，櫓 を組多梵天を立て，整然と地割りされた地域化軒を並べ て居て，市立の脹いを現している。

2) 九條富

会式の市立の㭔び物に富䇛があった。金毘羅富又は九 條富と呼ばれ，金山寺町で開札が行われた。

この富䇳は「九條殿御寄付大磐若米入札……」(注9) と 言う名目で文政 8 年 (1825) 加ら始った。京都九條家が 金光院に働き掛け，金光院が高松藩寺社奉行から許可を 受け，町方の世話人により催された。九條富は後に金毘 羅大芝居の定小屋を建設する理由の一つになる。

高松藩では富襶を初め 10 ケ年の期限付で許可した。

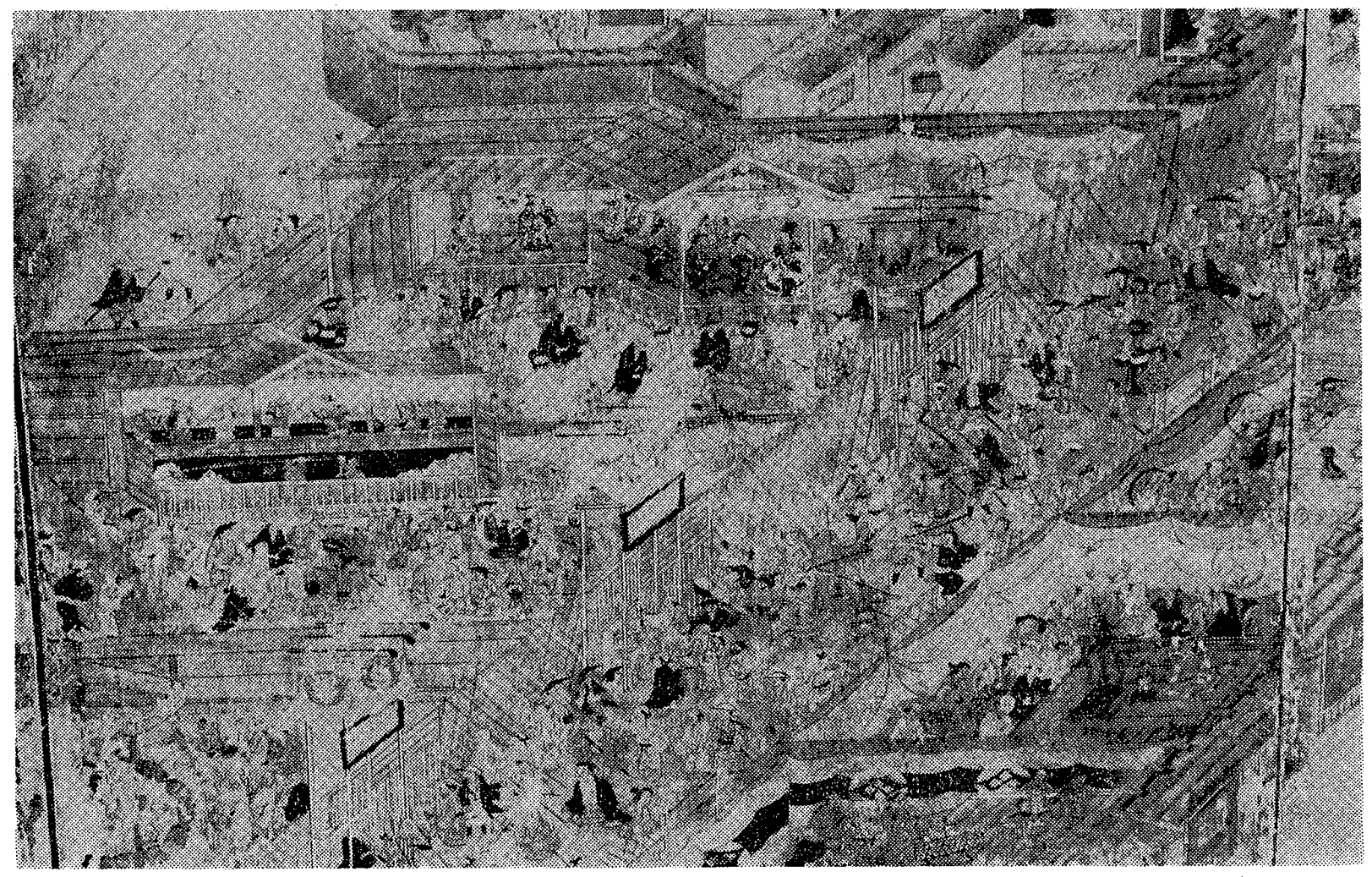

图一2 金毘羅祭礼図屏風(部分) 
文政 8 (1825) 年から天保 5 年 (1834) 迄で 10 年年経 過 したが，残り月，休み月があったと言う理由で，金光院 より高松藩寺社方に 天保 6 年 (1835) 10 月迄日延を要請 し(注10), 更に天保 6 年 (1835) 7 月には，向5 10 ケ年の 興行許可を得ている(注11)。

在来富の開札場所は，金山寺の芝居小屋が脚る所に富 小屋も仮設されていたが，芝居小屋を会式の度毎に建替 える経費を省く為定小屋とし，富の開礼場と兼ねれば双 方共入目隇になる旨の願書が出され許可になった(注24 参照)。

天保 6 年 10 月 9 日より定小屋になっての芝居が始 り(注12)，同年 10 月 13 日に定小屋を用いての初の富の開 札が行われた。その時の模様を「多聞院片岡章範日帳」 の同日の項に次の通り記されている。

……右御講之日八，入札相済申候迄芝居相休二や，木戸口へ九 條栐御紋付之御幕張リ，内八栈䑤入勘定場買方，舞台真中へ買 箱餙リ，同所二而開札以先し䐅，御用人八西側栈敷二罷有候， 九條梂御紋付之御幕 $ᄏ$ 張リ，代官警固八御山之御幕張也，高張 も勿論上之也......

な打「多聞院片岡章範日帪」による天保 5 年 (1834) 以降の富興行の記録は次の通りである。

天保 5 年 3 月 5 日の条 ( 3 月㹥興行中止)

一, 九佟様御講会, 去月廿二日騒動間も無之, 御無用二相成…… (天保 5 年 2 月当地で米騒動があった)

\section{天保 5 年 8 月 19 日の条 (9月は興行)}

一, 九佟様御講会, 當春乱妨, 御遠虑二相成居申候所, 吉田继 助殿占寺社方へ内談相済, 九月胡日興行二相定, 今日建札張紙 指出候事

天保 6 年 10 月 13 日の条 $\quad(10$ 月は興行 $)$

一, 九佟様御講会分, 定小屋二而興行二相成候事.

天保 7 年 3 月 10 日の条 ( 3 月は興行)

一, 九條㥞御講会, 寄高六千七百五拾八枚

天保 7 年 10 月回日の条

(10 月は興行)

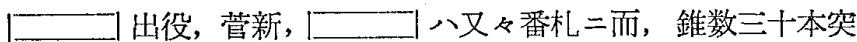

八，壳当り二付六十六多六分，相渡申候

天保 6 年 3 月の興行は，史料がなく不明である。

金毘羅と九條家との関係を遡って見ると，金光院 8 代

別当宥…(1691-1736) の時代加ら始っている。

金毘羅は 330 石の朱印地で 社領内の統治権はあった

\begin{tabular}{|c|c|}
\hline $\begin{array}{l}\text { 別当宥山（8代） } \\
\text { 元禄 } 4 \text { 年一元文元年 } \\
\quad(1916-1736)\end{array}$ & 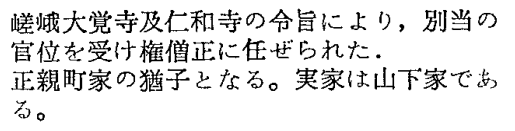 \\
\hline F（宥山 妹） & 菅家に嫁いだ。 \\
\hline 山下忠次郎 (有山 弟) & 京都所司代与力, 柳下家の盖子となる。 \\
\hline 巷辰可（キチの子,兄） & 信濃小路家の養子となる。 \\
\hline 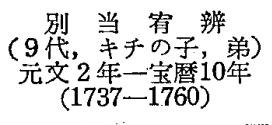 & $\begin{array}{l}\text { 権僧正を勅任された。権律師法眼となった。 } \\
\text { 維尾家の璔子となった。 }\end{array}$ \\
\hline 別当窝存 $(10$ 代 $)$ & $\begin{array}{l}\text { 権僧正を勅任された。 } \\
\text { 姉小路家の猶子となった。 }\end{array}$ \\
\hline $\begin{array}{l}\text { 高松藩坦 } \\
\text { 松平頼室 }\end{array}$ & 正親町家が実家である。 \\
\hline
\end{tabular}

が現実には高松藩寺社方の支配を受けていた(注14)。

高松藩主松平頼豊の室は正親町家の出であり，時の金 光院別当宥山は同家の猶子であった関係で, 有山の權僧 正任命は，正親町家の翰旋によるものと考えられる。

菅長可は，叔父柳下（山下）忠次郎の縁によって信濃 小路家の養子となった事から，8代䆜山の甥である 9 代 有辩の代となると，信濃小路家を通じて九條家と金光院 は一層密接な関係となったものと推定される。

金毘羅宮が宝暦 3 年 (1753) 勅願所となり，同 10 年 （1760）日本一社の綸旨が下ったのは，上記の正親町家， 信濃小路家等が九條家につながる家である所から，九條 家当主垸㛜の力による所が大きかったのではないかと考 えられる。この様な宮中との関係によって，9 代有辯か ら權僧正下命は䡃任となり，以後歴代別当はこれになら った。更に以後の別当はそれぞれ，油小路家，甘露寺家 等，九條家の縁故の家々の猶子となった。

この様に金毘羅は宮中よりの高い名分により，権威を 付けようとしたのに対して，九條家及びつながる家々は 絶えず金昆羅に金銭の無心を繰返した。その最たるるの が金毘羅に於ける九條富の興行であるら。

金毘羅が催す富興行は，治安の面からと幕府の天保改 革に上る富簁禁止の余波もあって，高松藩に遠慮勝であ った。しかし九條家では諸太夫，日夏筑前介を常駐さ せ，督励と交渉に当らせた(注15)。

天保 5 年 (1834) の九條家一 納めた富の 益銀は, 金百 五拾両であった(注16)。

3) 芝居

金思羅の芝居は，信仰を母体とした市立と芸能の密接 な関倸を保ち，相互に発展したものと考えられる。市立 が行わ机た時点で見世物，芝居等が行われたと考える。 市立の記録は「古老伝旧記」によると初代金光院別当， 宥範 (1270一1352) の時代迄遡る。

文政 8 年 (1825) の「諸国芝居繁栄敷望」大阪版によ れば，全国で 140 ケ所むの芝居小屋があったとされて居 て，金毘羅大芝居が定小屋になる 10 年以上前から 全国 的に芝居が繁栄していた。

「金毘羅名所図会」文化年間 (1804-1817) によれば,… 古老つたへ言ふ，むかし此の三の市のにぎわいにとて， 右の口及に諸目の角力人两つまり興行し，四天の柱高 く，さじき広くまうけたりしに，一年黑宙梅方助といふ わかもの，喧瞱の事ありてより，なにとなく此角力の勢 ひ今のごとく芝居・軽業にうつりて，角力の方は絶えは てたりとぞ…...

と大祭の市立の時, 角力加ら芝居等に移ったいきさっ が記されている。又「古老伝旧記」にも

一, 窘眼法印様御代迄八, 勧進相撲有之, 芝居仕切場八橋分外, 只今之彦四郎屋敷裏田之分二而，小屋掛り申候由，黑甶梅之助 喧㳸撫此処二而, 有之由申伝へ 
とある。史料の内の宥眼法印の在職は，慶長 18 年 (1613) より 正保 2 年 (1645) であるから，上記の事件はそれ以 降であろう。両史料共, 黒田梅之助の喧嘩から芝居中心 になったとする。これが金䍡羅に於ける芝居の記録に残 った始まりである。

「古老伝旧記」より，芝居興行の移り変りを記した條を 探ると次の通りである。

一, 只今, 檀之下芝居小屋掛厅候所者, 峟典法印御代永代二相 極リ, 多聞院市支配故, 地床屯芝居請候者共入割渡来り候事

一，芝居之義前ヶ $6 ， 三 月 八$ 新町横丁，六月八高薮町，十月八 金山寺町二極り居申候所，文政十式五年，有天様思召二而，三 季共金山寺町二相成候事

(なお，壇之下芝居とは金山寺町に於ける芝居である。 筆者注)

これらより，芝居が金山寺町に定着したのは，正保 2 年 (1645) より寛文 6 年 (1666) 迄の別当有典の㭙代であ ったこと，3月市の新町横丁の芝居や 6 月市の高数町の 芝居共, 金山寺町に移り定ったのは文政 12 年 (1829) で あった事が知れる。

「山下堅磐文書」(注17)の天保 9 年 (1838)の 金山寺町火 苂の項によると，

一, 今夕九ッ半, 金山寺町東側裏, 羽問屋絴次居宅 6 出火, 暁 七ツ時過鎮火之事

と市り，金毘羅大芝居の位置する金山寺町は，天保 9 年 4 月 11 日大火に見舞われた。

「金光院日帳」(注18)にも

一，今暁六ツ時前，出火相鎮申候段，左之者㴰上申出候事 $\cdots$

と天保 9 年 4 月 11 日の 火災が記録され，火災の見取 図(図3)も記録されている。この図の上部（西）に常舞台 があり，類焼からはま妨れている。この史料によっ $て$ ，金毘羅大芝居の金山寺町に於汀具体的な位置を知 る事が出来る。
金毘羅 に於ける 芝居の内容は, 珼永元年 (1704) 頃の 時点迄は, 竹田芝居等に代表される上方の芝居を軸とし て興行されていた事が「古老伝旧記」(社19)に述べられて いる。文政から天保にかけて，芝居が全国的にはやり， 金毘羅へ乗掛けて来ないため，御会式が脹わしくならな いので，上方へ行き良い芝居を請ける相談をしている事 が「古老伝旧記」(注20)と「多聞院片岡章範日帳」(注21)に 記述されている。この様に，芝居小屋が定小屋になった 天保 6 年 (1835) 以前加ら，金毘羅の芝居は上方に依存 しており，皆小屋の建築様式は上方の影響を受けたもの と推定される。

金毘羅では，3 月と10 月の市立の折芝居が興行され， 興行日数は原則として 30 日間であったことが次の「多 聞院片岡章範日帳」(注22)で知れる。

一，芝居三十日願済之所，三十六日興行致候義，いか子と寺社 方 6 尋有之, 役者不快雨天, 御前病気中等二而相休足し, 六日 相勤候段申答候事

\section{2. 建設の諸問題亡年代考証}

1) 願いと許可

天保 5 年迄は，3月，10月の会式の際の芝居は金山寺 町に於いて仮小屋をその都度建て興行されて来た事は， 前記の「古老伝旧記」に記述され, 又「金光院御用留」 の口上之覚の内に「社領芝居小屋之義是迄会式之度每二取建 申義二御座候所……とある所からも明らかである。

天保 5 年 12 月に町方から 金光院組頭に，芝居定小屋 の件を打診した(注23)。

更に天保 6 年 1 月 28 日に，金光院より高松藩寺社奉 行へ，会式の度每に仮小屋を建てるのは費用がかさむの で，瓦莫の定小屋としたい旨が町方より起きている。芝 居と合せて富の開札場としても用いたい。定小屋となっ ても定芝居は致さない旨の願書が出された(注24)。

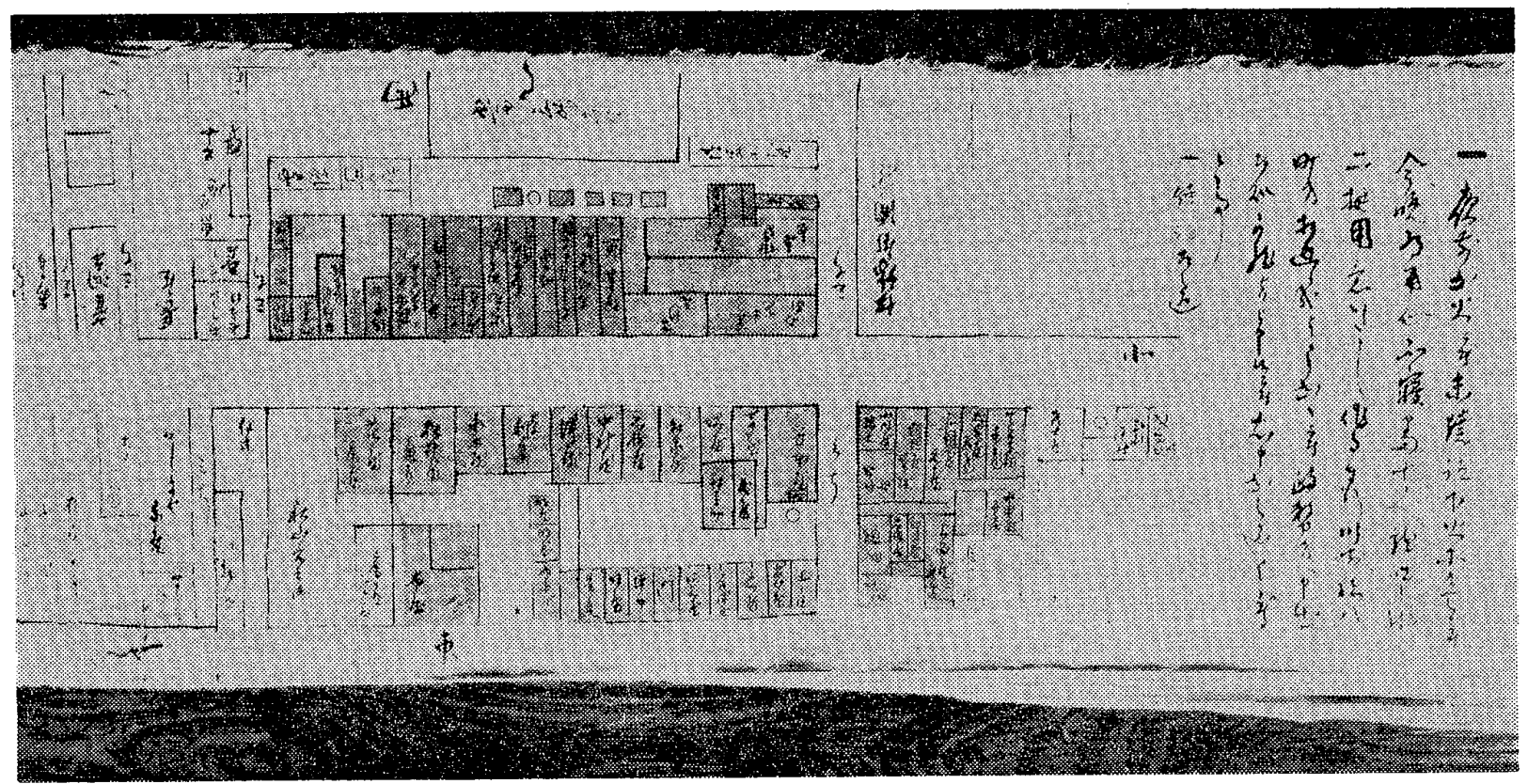

图一3 金光院日帳 天保 9 年 4 月 11 日の条 
この願書に対して，高松藩寺社方より許可の返書が同 年 2 月 5 日付で, 金光院に与えられている(注25)。

2) 資金関係

定小屋建設に要した費用は, 門前町の酌取女, おやま の花 1 本代 3 文づつ刎ね積立てたものを使用した。

一, 右普請入目は, 酶取女, 抔户安之花壱本代, 三文つつ之内 刎銀之名附 $\square \square$ 除置, 宿場方々取立年寄手元人指出, 夫 $习$ 多? ヤ次兵衛へ預ケ，其銀

この刎銀は普請の費用だけでなく，芝居興行の役者の 給金の補助にも用いて奖励したとも言われている。

3）用材について

芝居小屋建設の用材は, 箱御崎(注27)で調達し, 海路, 中津の浜(注28) を経て丸亀へ運んだ。当時他の街道に比 べ最も整備され運搬が容易であった為か, 丸偖街道への 経路を経て現場へ運んだのであろう。用材に関する次の 「多開院片岡章範日帳」よりすれば，この材木注表向き は当時建設中の金堂(注29)の用木と申立てて, 人足も集め 番所を無難に通ったとして居るが，この番所は経路から 見ても丸龟藩の番所であり，金光院の芝居小屋建設につ いて丸亀藩に対する遠慮がらかがわれる(注30)。

4) 作事組織

天保 6 年 2 月 5 日付の定小屋普請の許可が高松藩より 下りると, 金光院によって作業奉行, 普請引請人及差添 人が申付けられた記録が, 天保 6 年 5 月 13 日の「金光 院御用留」にある。

一, 此度, 芝居定小屋願済出来候二付, 右普請掛り作事奉行両 人江, 掛り申渡候事

作事泰行屋普請掛り（高䓩茂川售之助

芝居小屋普請二付, 町方二而掛少之者, 左之通申付候事 金川屋清右衛門
此度, 芝居定小屋普請引請人二申付候間, 諸事気を付, 差添人 共申合為宜栐, 取計可申候

二葉屋林平
夌兵衛
登茂屋久右衛門
花屋 蔵

此度, 芝居定小屋普請引請, 清右衛門人申付侯間, 其方共差添 人二申付候, 清右衛門申合随分為宜様, 取計可申候

翌日の天保 6 年 5 月 14 日の「金光院御用留」には, 引除掛り の作事奉行と町方の者が申し付けられている。

一, 芝居定小屋普請二付, 今日名左之者引除掛少, 被仰付候事

$$
\text { 作事奉行同 }
$$$$
\text { 高木隼人枝茂川圭之助 }
$$

$$
\begin{aligned}
& \text { 若木や 直 助 } \\
& \text { むき户 作兵衛 } \\
& \text { 金川户 清右衛門 } \\
& \text { 之も户久右衛門 }
\end{aligned}
$$

これで作事組織は知れる。なおそ括他, 工事関係者につ いても若干の事実を知れる史料がある。

たとえば丁斧初の大工は次の者達であった。

一, 芝居定小屋, 今日丁斧初有之, 棟梁大工西屋長兵衛, 大工 勘助(注31)也，但し，勘助は地方百狌二而，善太夫之事也(注32) 地割縄張の際の掛りは，次の者たちによってなされた。 一, 芝居定小屋, 願相済申侯二付, 昨日左之通罷出, 地割いた 乙中候事.

$$
\begin{aligned}
& \text { 地方役 } \\
& \text { 高木隼人 } \\
& \text { 作事方 } \\
& \text { 川崎猪八 } \\
& \text { 町年寄 } \\
& \text { 井上太郎左衛門 } \\
& \text { 町方手代 } \\
& \text { 秋山吉兵衛 } \\
& \begin{array}{c}
\text { 地方纈 } \\
\text { 次 郎 } \\
\text { 次 }
\end{array} \\
& \text { 肝煎壳人（注33） }
\end{aligned}
$$

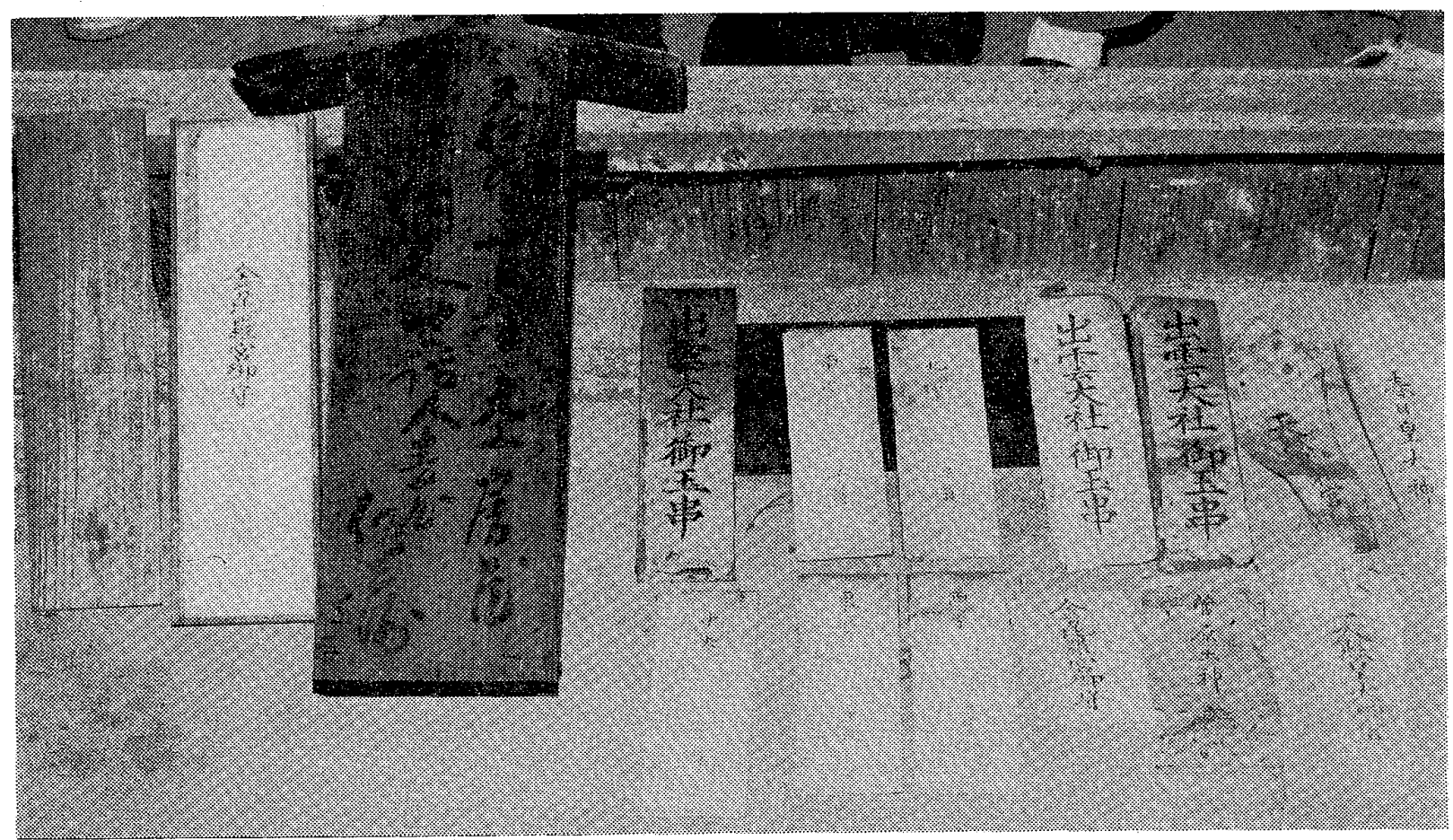

図一4神札入及神札 昭和 43 年 3 月 佐藤研究室撮影 


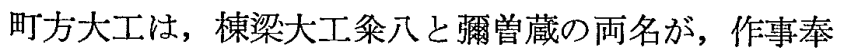
行より申付けられた(注34)。

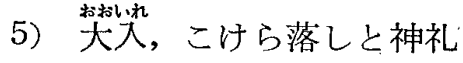

金毘羅の大祭は 10 月 10 日であり，その前日の 10 月 9

日に定小屋が完成し大入，こけら落しが行われた(注35)。

大入は芝居初日の前日行われ，役者の拉目見得披露の ため無料で芸題の一幕を公開した。翌天保 7 年 (1836) 10 月 9 日にも，その記録が見られる(注 36$) 。$

昭和 43 年 3 月の現地調查の際, 大臣通りの当初小屋 組の真束に，荒神型の神札入が取付けられていた。神札 入の裏書には「天保六年末十月八日大工房藏納之世話人 麦屋作兵衛」とあった。房蔵とは花屋房蔵の事で, 普請 引請差添人としてもその名が見られる。麦屋作兵衛は房 蔵と同様普請引請差添人の他, 引除掛りの町方としてを 名が見られる。

神札入に書かれている，天保 6 年未 10 月 8 日の日付 は, 大入の前日である所から見て, 今の建物が天保 6 年 創建である事が確認出来る。神札の面からも「金䍡羅宮 御守」「象頭山金毘羅大權現守護処」の名称は, 古来加 ら明治 22 年迄用いられたが，「金刀比羅宮御守」の名称 は, 明治 22 年以降からであるので, 前者汢天保創建時

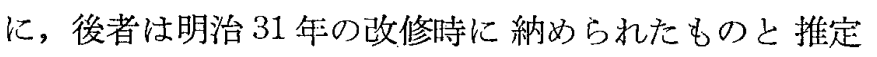
される(注37)。(図 4)

6）建設過程と日程の検討

芝居小屋建設に関し，史料に残る記録を日付順に列举 すると次の栐になる。

イ. 天保 5 年 12 月 多聞院片岡章範日帳 (夲保 6 年 2 月 8 日)

口. 天保 6 年 1 月 28 日 金光院御用留

八. 天保 6 年 2 月 5 日 金光院御用留

二. 天保 6 年 5 月 13 日 金光院御用留

小. 天保 6 年 5 月 14 日 金光院御用留

人. 天保 6 年 7 月 25 日 多聞院片岡章範日帳

卜. 天保 6 年 7 月 26 日 金光院御用留

于. 天保 6 年閏 7 月 11 日 多聞院片岡章範日帳

リ. 天保 6 年閏 7 月 26 日 多聞院片岡章範日帳
町方から定小屋普請につい ての打診を金光院組頭に行 った(注24. 参照)。

金光院から定小屋普請の願 いを高松藩寺社へ上申乙 た(注25. 参照)。

定小屋普請願済となる (注26. 参腭)。

普請掛り作事奉行と, 町方 普請引請人及び差添人が申 付けられた (4. 作事組䋊.参膘)。 引除掛りの作事奉行と町方 の者吕申付られた (4. 作事組 織.参照。

定小屋の敷地を南北 22 間， 東西 16 間 と定めた(注38)。 敷地の地割り見分を行っ た(注39)。

定小屋の用材を調達し, 金 堂の用木として現場へ運ん だ(注 30 . 参照)。

丁杀初めを行った (4. 作事組 織参照)。
ヌ. 天保 6 年閏 7 月 27 日 山下堅磐文書

ル. 天保 6 年閏 7 月 28 日 山下堅磐文書

地割り，緡張りを行い，地 面の買上げを町年寄に申渡 した(注40)。

F. 天保 6 年 8 月 16 日 多聞院片岡章範日帳

ワ. 天保 6 年 8 月 23 日 山下堅磐文書

力. 天保 6 年 9 月 1 日 多聞院片岡章範日帳

ヨ. 天保 6 年 9 月 18 日 定小屋が上棟した(注42)。 金光院御用留

夕. 天保 6 年 9 月 26 日 多聞院片岡章範日帳

レ. 天保 6 年 10 月 9 日 多聞院片岡章範日帳

栈敷の触れを取りきめた (注44)。

今夕に大入を行った(注 36 .参 照)(注45)。

ソ. 天保 6 年 10 月 13 日 定小屋で初めて九條富の興 多聞院片岡章範日帳 行，入札を行った(注46)。

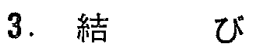

金毘羅の市立と芝居の関係注古く，宥範の頃の文永 7 年 (1270) 以前より市があり, 芝居も省眼の代の 慶長 18 年 (1613)より正保 2 年 (1645) の閒に始った。

京都九條家と金毘羅は，九條家につながる家々との縁 によって京都は名誉を与え，当時窮艺の九佟家は金昆羅 に金銭の無心と文政 8 年 (1825) からは富興行をさせた。 この事が芝居を定小屋にする動機の一つになり，又門 前町を一層繁栄させる事にもなった。又定小屋の建設費 用を芸妓の線香代の刎銀で賄ったと言う事は，金光院と 門前町の町方達との利害関係が一致して居た事を示して いる。

金毘羅の芝居は，前述の「古老伝日記」にある様に， 古くから上方の芝居を主軸とし，上方様式の興行が行わ れをと考えられる。

享保 9 年 (1724) 以降, 幕对は公許の伝統を有さない 新劇場の設立は許可されない筈であったのに(注47)，本劇 場の場合注常芝居ではなかった事と，金光院が九條家を 背景とした政治的勢力が大きかった事，等により高松藩 も定小屋として建設する事を許したのではないかと考え られる。

劇場の創建年代は，天保 6 年閏 7 月 26 日に丁斧初め が行われ，同年 9 月 18 日に上棟し，同年 10 月 9 日に大 入が行われた事が史料により明らかとなった。又，発見 された神札入れの日付けからも, 今の建物が天保 6 年創 建のものである事を確認する事が出来る。

\section{あとがき}

本稿の研究に関し日本大学堀込憲二助手には史料收集 に，金刀比羅宮図書館松原秀明氏には各種の史料の提供 
を受ける等，昭和 43 年以来引続き協力して頂いた。

日本大学教授近江栄博士には, 此の研究を学会報告集 に報告する様铨められ，且多くの教唆を賜った。日本大 学教授山口広博士には, 本稿の構成その他について教示 を賜った。ここに深く謝意を表したい。

\section{引用文献（注）}

1）佐藤孝義, 山岡永知：歌舞伎劇場の機能分析一金丸座（香 川県) について, 昭和 43 年日本建築学会関東支部学術研 究発表会

佐藤孝義，山岡永知：歌舞伎劇場の機能分析一金丸座の 実態調査, 昭和 43 年 10 月日本建築学会大会学術講演会 佐藤孝義，山岡永知，堀込憲二: : 金丸座実態調査報告 そ の 2 . 昭和 45 年 9 月日本建築学会大会学術講演会 日本大学生産工学部佐藤研究室：「金丸座」の実態調査及 復元，昭和 45 年 9 月日本大学学術助成金受領論文 伎藤孝義，山岡永知，堀込憲二：「金丸座」の実態調査及 復元, 昭和 45 年 11 月日本大学生産工学部学術講演会

2）勅願所，日本一社の綸旨については，「讃岐国金毘羅神社 興隆馆」第二十一所収, 「讃州象頭山金昆羅神社興隆之 事」第二十四所收，金刀比羅宫社務所蔵，等に記録があ る。

3）華山牧野宗称筆, 浪花今城江南住, 成为堂蔵版, 金刀比羅 宮社務所蔵，金鼠玀宮境内の金堂方完工（弘化 2 年 1845） している。境内北神苑の高燈籠が未建 (安政以前) 等の事 加ら弘化 (1844-1847), 嘉永 (1848-1853) 頃の景観で あると推定する。

4）「琴平に拈ける遊女について」武田季雄，「ことひら」50 年新春号，琴平山文化会刊 p. 51 所収出典. <琴陵宮司所 蔵文書, 文化…(1824) 申三月酌取女雇入茶屋同宿一同人 申渡云々事>

5）献燈の燈笔には寄進者名, 居住地名, 屋号, 職名, 講名, 寄進年代，取次宿名，世話人名が台石に刻番れている。

6)「多聞院秘帳古老傳旧記」高松市片岡家所蔵文書 : 多聞院 は金毘羅 5 院の 1 つで，市立・芝居等の町方の担当であ った。4 代慶範の宝暦頃 (1751－1763) の記述で甫立・芝 居について記載してある。

金毘羅会式之事

一，十月市八往古份有之，御会式年数不知，頭人之神事 祭禮，金光院宥範上人御代御控之通之由也〈筆者注，宥 範は初代金光院別当文永 7 年 (1270)一観応 3 年 (1352)〉 一，六月市八往古分有之，観音御会式別当八西琳坊之由 一，三月市八新市也，宥典法印御代新町出来候而，其節 町方重立候者共願候而, 市取立候由〈筆者注, 有典は 6 代金光院別当正保 2 年 (1645)一宽文 6 年 (1666)〉

7)「象頭山金昆羅大權現霊験記「明知 6 年 (1769) 上样, 金 刀此羅宮図書館所蔵，例年，三月八日 会と言有……

8）狩野休円清信筆，金刃比羅宮社務所所蔵，休円清信は竞 保 2 年 (1717) 没

9）「金光院御用留」文政 8 年 (1825) の条，金刀比羅宮図書 館所蔵

10）「山下堅磐文書」天保 4 年 (1833) 10 月9 日の条: 写「金 刀比羅宮史料」第 50 巻，第 51 巻，金刀上比羅宮社務所所 蔵

一，九條様御講，当年限二而十ケ年相済候得共，いまた 残リ月休ミ月等有之侯二付，拾ヶ年之月数相满不申，明 年十月迄此侭御催相成候，高松表 ——| 相調，九條様 へ6右之旨 一御趣向二取掛少侯事

11）「金光院御用留」天保 6 年 (1835) 7 月 29 日の条，金刀比 羅宫図書館所蔵

一，昨日，九條殿御寄附大䑾若講，延年相済候段左之通 申来候

一筆令啓上候，然者於御社領，九條殿占御寄付之大磐苔
講, 当十月二而满講二相成候処，今拾ヶ年被相催御同所 6 御願二付，又当十一月分来ル已之十月迄，拾ヶ年之間 年延之義申出之通相済候閒，左様御心得可被成候，恐惶 謹言
七月廿七日
筧 又蔵 金 光 院

12)「多聞院片岡章範日艮」天保 6 年 (1835) 10 月 9 日の条, 山下盛好写（安政 5 年）琴平町渿原俊三氏所蔵，一，芝 居今夕大入初日いたし候事

13）「進退録」山下盛好編军本，琴平町营納彰次氏所蔵 「山下家家譜」山下盛好編写本，琴平町漆原俊三氏所藏 「官位昇進記」写「金刀比羅宮史料」第 45 巻, 金刀比羅 宮社務所所蔵

14）「讃岐国金昆羅神社興隆記」写「金刀比羅宮史料」第 21 巻, 金刀比羅宮社務所所蔵

15）日夏家は信浱小路家の分れで㐫り，九涤家の諸太夫であ った。

「多聞院片岡章範日帳」天保 7 年 (1836) 3 月 16 日の条 一, 日夏筑前介殿, 九條家御代参として下向致内実八, 御請上金之掛合也

16）「金光院御用留」天保 5 年 (1834) 正月 21 日の条

一, 金百五拾両, 右者御講御益近年のならし, 一ケ年分 百四拾九両武步二御座候間, 凡此割合 7 以御会每寄高応 乙，上納可仕候，寄り高多少二 6 少 2 者増減可有御座候

17）「山下堅磐文畫」天保 9 年 (1838) 4 月 10 日の条

18）「金光院日帳」天保 9 年 (1838) 4月 11 日の条, 金刀比羅 宮図書館所蔵

19）一, 竹田芝居古来分, 自身当地八参候時分者, 御寺 $\hat{f}$ 米 武俵宛被成下，地床も極り有之也，然共近年近江出雲之 も二自身不参，竹田代尖参侯故米者不被下候事. 竹田芝居, 「上方演劇史」堂本寒星著, 春陽堂, 昭和 19 年発行,

「竹田からくり座の竹田近江は 万治元年 (1658) 京都で口 宣を得て竹田出雲掾となり，寛文 2 年 (1662) 大阪道頓堀 浜側でからくり座を始めた。竹田の芝居は中芝居で後に 中歌舞伎となった」

20）……名き芝居三ッ斗り，あやつり二ッ三ッ，小見世す 数々有之他，近年者芝居諸国二而はやり仕候故，乗掛ヶ 不参故, 国々好々6も請元方 6 才覚之, 上方へ登旧事 也，当地芝居数茂相極少，諸元一札差出乙之通免申候事

21）「多聞院片岡章範日帳」天保 7 年 (1836) 7 月 19 日の条 一，当所芝居人，大阪之役者請候義相成候段，寺社方 6 申越，夫二而八御会式秷不不申何分能役者請申度内 談として，川崎猪八高松へ参り侯事.

22)「多聞院片岡章範日帳」天保 7 年 (1836) 5 月の条

23）「多聞院片岡章範日帳」天保 6 年 (1835) 2 月 8 日の条 一, 当所芝居定小屋, 願出候願書入割 — 甚助殿内 證発言之事, 表向願人左

二葉屋林平

$$
\text { 天保五4十二月 }
$$

\section{若木屋直助} 金川屋清右衛門

組頭 彦左衛門殿 大和屋久太郎

\section{同喜兵衛殿}

24）「金光院御用留」天保 6 年 (1835) 2 月の条 口上之覚

社領芝居小屋之義，是运会式之度每二，取建申義二御座 候所，入目多分二而難渋仕候間，瓦贵定小屋二仕度旨， 町方之者共願出申候，尤大般若講入札場所も兼而，定小 屋二仕御座候間, 右芝屋小家出来候得八兼合二相成申率, 双方入目減二而, 勝手二相成候趣事も願出申候, 右之通 定小屋二八仕候得とも，常芝居之申二八無之，芝居之義 八是迄之通, 度每二申出仕義二候全, 常小屋二致置計二 而御座候間，申出之通二為致可申哉と存候，其段宜存候 金光院 


\section{三木七郎右衛門様}

$$
\text { 筧蔵様 }
$$

25）「金光院御用留」天保 6 年 2 月の条

一筆令啓上候，然者御社領芝居小屋定小屋二致度段，願 出候間，申出之通致也度由，御申出之通相済候間，左様 御心得可被成候, 恐憧諤言

$$
\text { 二月五日 }
$$$$
\text { 三木七郎右衛門 }
$$

金光院

26)「多聞院片岡章範日帳」天保 6 年 8 月 16 日の条

27）箱御崎とは，現在の香川県三崎半島の先にある箱崎の事 と思われる。

28）中津浜とは，昔は丸菓と多度津の間あたりの浜を「津」 そ呼えでいたので，その中程の所を指すむのと推定する。

29）当時金昆羅では金堂の建設が始って居り,天保 8 年 (1837) に竣工している。

30）「多聞院片岡章範日帳」天保 6 年閏 7 月 11 日の条 一，芝居定小屋之材木，箱御崎二而相調，中津之はまへ 着いたし，夫万丸龟へ相迴し引上侯二付，町中人足相触 引申候，尤表向八金堂之用木と申立候也，御山が八足 壱人へ米五合つつ被下候事，但し，好重中府口之木戸二 引当，番所分彼是申候得共，金堂用木之段申立，断無難 引取申候，町々 分役人代壳人つつ出申候事.

31）大工甚助は金光院の命を受け，大阪道頓堀の筑後の芝居 を克明に控えて帰り，それを模して金毘羅大芝居を設計 したと言い伝えられている。

32) 「多聞院片岡章範日帳」天保 6 年閏 7 月 26 日の条

33）「山下堅磐文書」天保 6 年閏 7 月 27 日の条

34）「山下堅磐文書」天保 6 年 8 月 23 日の条 一, 芝居小屋, 大工棟梁町方大工, 条八, 彌曾蔵両人へ 申付趣，作事奉行川崎猪八万申出候事

35）「多聞院片岡章籁日帳」天保 6 年 10 月 9 日の条 一, 芝居, 今夕分大入，此度定小屋出来初而也，

$$
\text { 勧進元 二葉や林平: }
$$

36）「山下堅磐文書」天保 7 年 10 月 9 日の条 一, 大芝居, 今日大入, 勧進元, 森屋久蔵, 役者八, 浅 尾興六，中村歌十郎，中山み上乙，右之外記有之侯得共 略す，大当り大当り，
外題，増補忠臣蔵，日本花義士文章

37）神札入には，金刀比羅宮御守 2 枚，金毘羅宮御守 1 枚, 象頭山金毘羅大權現守護処 1 枚, 東 - 西・南・北・中央 守護の神札各 1 枚, 出雲大社御守 3 枚, 天照皇大神宫御 守 2 枚, 春日皇大神宮御守 1 枚, 菅原大神宮御守 1 枚の 計 16 枚の神札が納められていた。

38）一，芝居定小屋土地，今日見分，先不取敢，南北廿八間, 東西十六閒と見定侯事

39）一，今日，金山寺芝居定小屋，地割見分之事

40）一，芝居定小庫二相成候二付，地面相定申候二付，見分 相済, 地割いたし, 縄張御座候, 地面御上ヨリ御買上ケニ 相成候二付，地面持主八町年寄 6 申達候様申達候事

41）一, 芝居定小屋, 今日 6 地形二取掛り申候事, 但し, 作 事奉行引受二相成, 手代安藤兵蔵, 森藤常衛門, 一日替 リ二能出候事

42）一，芝居定小屋，士地上ヶ申候二付，今明日砂持初少， 芸子沶や案や之若者共, いるいる之出 $[$ 二而, 町中賑 々敷踊り廻リ，砂持候事.

43）一，芝居上槙之事

44）一，芝居定小屋出来，栈之御触之事，取約风いら

45）天保 6 年 10 月 9 日大入，こけら落しと異なる史料に次の ものがある。

「萬延元庚申三月御当山御開帳二付諸方三里上納物並二当 所賑と上納物細書」金山寺町 花屋房蔵述

\section{琴平町 草䕌金四郎氏所蔵}

一，当時，芝居定小屋，去儿天保七年申年建ツ，夫名相 続，芝居興行致来候

この史料で注天保 7 年 (1836) に建ったとして， 1 年遅く なっているが，天保 7 年より 24 年後の万延元年 (1860) の記録であり，年代考証に難を感ずる。天保 6 年完成の 史料は，前記の如く建設過程の記録がある程度揃ってい る上，神札入の日付も天保 6 年 10 月 8 日である所から， 天保 6 年 10 月 9 日の定小屋となって初の大入が自然な考 え方であると思われる。

46）一, 九條様御講, 当会分定小屋二而, 興行二相成候事.. …右御講之日八，入札相済申候迄，芝居相休二や

47）「日本劇場史の研究」須田敦夫著, 相模書房, 昭和 41 年 発行, p. 334 . 


\section{S Y N OPS I S}

U.D.C. $725.822 .03(\mathrm{Ko})$

THE STUDY OF KOMPIRA OH-SHIBAI THEATRE

Background of Conception and Construction of the KOMPIRA

OH-SHIBAI Theatre

by TAKAYOSHI SATO, Professor Nihon University, Member of A.I.J.

This thesis is a research report on the KOMPIRA OH-SHIBAI theatre which has been preserving the tradition of KAMIGATA THEATRE of the Edo period. KAMIGATA means the Kyoto-Osaka area. This theatre still remains at Kotohira-cho in Kagawa Prefecture which is the gate town of KOTOHIRA-GU Shrine. This thetre is the oldest authentic KABUKI theatre which is still existing and one of the few preserved constructions which were constructed in the Edo period. The town has been prosper with many worshippers for cermonies, memorial days market and lottery in the Shrine. People manted a theatre in the town and the theatre became the most popular building in the town and respected as the center of populace culture. This building wos constructed in the six year of Tempo (A.D. 1835) and is still maintained after a number of repairs until now.

The author believes that this building is one of the most precious relics in the history of theatre construction and drama performance in Japan and the architectural study of the building is very important in the research of the origin and genealogy of KABUKI Theatre construction.

CONTENTS :

PREFACE

1. CONCEPTION AND CULTURAL BACKGROUND

1) The gate town and memorial days market

2) KUJOTOMI (lottery)

3) SHIBAI (populace drama)

2. CONSTRUCTION PROGRESS AND CHRONOGICAL STUDY

1) Motivation

2) Funding

3) Procurement

4) Organization

5) Opening theatre date and chronological study of amulets

6) Construction stages and scheduling

3. CONCLUSION

POSTSCRIPT 